\title{
The Concept of Communities of Practice on the Example of IT Sector
}

\begin{abstract}
Izabela Sztangret
Department of Market Policy and Marketing Management, University of Economics in Katowice, 1 Maja 50, 40-287, Katowice, Poland, izabela.sztangret@ue.katowice.pl
\end{abstract}

Background: A growing interest in the concept of communities of practice (CoP) has been recently observed in several academic fields. They include organizational studies (the topics of knowledge management and organizational learning in particular) and education. However, the notion is used in various contexts. It is sometimes perceived as a social construct, but at some other times as a virtual community or informal group sponsored by an organization for the purpose of making it easier to share knowledge or learn.

Objectives: The main aims of the paper are: 1) to identify the main characteristics of the CoP in IT sector, 2) to identify and describe the knowledge management tools used by CoP, 3) and to identify and analyse customer knowledge of CoP.

Method: The research assumed an exploratory character. The case study and survey methods with application of structured questionnaire were used.

Results: The CoP is little effective form of stimulating business processes and market, despite application of a broad range of activities undertaken for the purpose of creation of the so-called knowledge communities by the entities of IT sector and internet activity declared by respondents.

Conclusion: Poor knowledge of CoP as well as the awareness of participation in its structures among the recipients, who are additionally active users of new technologies including mostly the Internet, may also be caused by the lack of experience in the sphere of studied knowledge-based relationships or priority character of ventures of directly measurable business results. Determinants of CoP creation and directions of its development may constitute an interesting area for further studies.

Key words: knowledge management, marketing knowledge management, community of practice

\section{Introduction}

As organizations grow in size, geographical scope, and complexity it is increasingly apparent that sponsorship and support of groups such as community of practice $(\mathrm{CoP})$ becomes a method of increasing the effectiveness of business processes, including creation of target markets. Communities of practice become the object and the tool of knowledge management, and marketing knowledge management.

Thus, this article aims at defining CoP forms and their tools. The main sources of theoretical analyses are scientific literature and journals, specifically those publications devot- ed to $\mathrm{CoP}$ as knowledge management tool. Next section concentrates on a case study, based on the entities of IT sector, which have used a broad range of activities and tools for the creation of the knowledge communities. Intel company is one of the leaders in implementation of researched concept of community. The identification and grouping of the CoP's tools were the research goal, in this part. The method of critical analysis of Internet webpages of IT sector leaders in Poland and in the world, and the analyses of articles, particularly of sponsored interviews presented in specialist IT magazines, were applied. This article aims at identifying and describing the customer knowledge of CoP, too. This 'customer knowledge of CoP' is expressed, among others,

Received: $21^{\text {st }}$ November 2013; revised: $18^{\text {th }}$ April 2014; accepted; June $16^{\text {th }}, 2014$ 
by their addressees' level of knowledge about the tools, and their involvement in communities of knowledge. To reach this goal, the survey method with application of structured questionnaire was used. Finally, results of the study are discussed and some conclusions are drawn .

\subsection{Community of practice in theory}

Marketing knowledge resources are such intellectual assets that are the sum of knowledge of employees, teams of employees, cooperating entities, network partners and customers that an organization applies in its market activities which may determine the structural dimension of knowledge management. In structural approach, marketing knowledge management consists in managing people and their competences, and it is a database of knowledge about the customers and cooperating entities, as well as exchange of information between the enterprise and customer / cooperating entity, for the purpose of acquiring, satisfying and retaining them. It is a system of tools, processes and culture that is developed for the purpose of improving, creating, sharing and applying specific knowledge for the process of making decision by corporation, including the marketing ones (De Long and Seemann, 2000).

Formation of long-term integrator relationships with network partners, including the customers, for the purpose of involving them in the process of external co-formation of particularly tacit knowledge while transforming tacit knowledge of the network integrator into explicit knowledge for internal environment of the network, is very important in marketing knowledge management (according to the Japanese concept of knowledge management, see Nonaka and Takeuchi, 1995, pp. 44-45). People often talk about 'community' or 'collectivity' of entities that jointly perform research and jointly use and multiply knowledge resources (Sawhney and Prandelli, 2000, pp. 44-45) for synergic creation of values. In many organizations, communities of practice have become an integral part of organizational structure (McDermott and Archibald, 2010).

The notion of Community of Practice (CoP) was formulated for the first time in 1991 by Jean Lave and Etienne Wenger (Aubry et al., 2011, pp.42-56). They defined it as the major element of their theory of 'situated learning'. This theory referred to workplace learning as the one that takes place through participation in practice and interaction with colleagues and not through formal instruction or training. The community of practice is described here as a group in which we observe learning processes as occurring among its members naturally as individuals become competent in practice. Becoming a full member of such a community depends on competence in other members' view (Lave and Wenger, 1991). According to Bredillet (2004), community of practice members 'learn by participating in the community and practicing their jobs'. At the beginning, the concept constituted an analytic aid that let describe how learning occurred in the workplace and then it became the tool for businesses applied to increase the 'knowledge assets' possessed by the employees (Ranmuthugala, et al., 2011). Community of practice is the concept that has been evolving and we can find its multiple forms can be found in reality. Scarbrough and Swan (2008) opted for accepting diversity in the forms of communities of practice. They perceive the concept of the community of practice as representing historically specific expression of self-strengthening relationships between learning, identity, group formation and social practices, rather than a separate discrete social grouping. Duguid (2008) indicated that the community of practice is currently a management tool: 'We also get a theory that appeals strongly not only to business schools, but also to management consultants: it is instrumental, operational, and promises only beneficial results'. Thus primary approach to learning perceived as improvisation and autonomy is no longer functioning and it is replaced by something totally opposite: following principles and avoiding improvisation of any kind (Lave and Wenger, 1991; Wenger and Snyder, 2000). Duguid (2008) perceives this managerial approach to the community of practice as a traditional viewpoint in which any form of improvisation and autonomy are overcome by control. Therefore the community of practice may be understood as being rapidly domesticated (Duguid, 2008). Nonetheless, Duguid (2008) stated that just like any other construct, this one is proceeding according to its own path. Wenger and Snyder (2000) presented an example of managerial domestication of the community of practice. They supported the idea of communities of practice as a new management instrument aiming at business results that included helping to drive strategy, starting new business lines and others. It can be stated that research into community of practice was targeted at two separate areas that might be referred to as organizational studies interpretation and knowledge management interpretation. The first field highlights the theory development while describing new organizational communities of practice. The other group stresses the business value of communities of practice aiming at identifying, supporting and / or launching strategic communities of practice for the purpose of managing organizational knowledge (Murillo 2011, p. 5). In the article, the second interpretation of $\mathrm{CoP}$ as the knowledge management tool is dominant.

Etienne Wenger uses the three elements of engagement, enterprise and practices to join the concepts of community and practice into a unitary construct. She does this by describing three dimensions of practice as the source of coherence of a community (of practice), i.e., as what makes that particular kind of community coherent. She thus describes them as constitutive or defining dimensions of communities of practice (Wenger, 1998):

1. Mutual engagement: members build the community and the practice by conducting practice-related interactions with each other on a regular basis. 
2. Joint enterprise: members collectively negotiate what their community is all about and hold each other accountable to this understanding.

3. Shared repertoire: over time, members develop a set of shared resources that allow them to get engaged more effectively.

The presence of these three dimensions in a group is a necessary and sufficient condition for the existence of a community of practice (Murillo, 2011, p. 5).

\subsection{Virtual communities of practice in theory}

Due to virtualization of the environment of functioning of entities, the concept of community of practice finds its place in the concept of VCoP (Virtual Community of Practice) that has been developed with reference to CoP concept. Virtual Community of Practice is a community of practice developed on the basis of Internet. According to CoP definition, in Lave and Wenger's opinion, VCoP must include active participants that are experienced people and experts in a specific area (Wenger, 2007). Community members must participate in the process of collective knowledge exchange and formation. They acquire knowledge in the process of learning and through relationships with the group, as a result of synchronic interactions (Wenger, McDermott and Snyder, 2002). CoP provides virtual space in which people participate without language, geographical or cultural barriers (Gray, 2004, pp. 20-35). Considering the level of activity of the participants, we can distinguish regular and peripheral activity of participants, consisting in information receiving and personal learning rather than co-creation of value (Riverin and Stacey, 2008, pp.45-58). Dubé, Bourhis and Jacob made a typology of virtual community of practice. According to their research they identified three major types: A, B and C (Hara, Shachaf and Stoerger, 2009, pp. 740-757):

- The intention of VCoP A creation is to offer its members a forum where they can share and discuss tacit knowledge and also develop a repertoire of the best practices in their specific area. The goal of an organization is to create the community of practice as a pilot project, to assess how successful it is and to evaluate the potential of tacit knowledge sharing tool. Possibly, they will apply this experience to establish other communities in other areas of professional expertise. Considering this specific orientation VCoP A is formed through a top-down process, however they are not integrated into formal structures of organizations, even though VCoP A members are all professionals in the same field of expertise.

- VCoP B is established deliberately by the management of an organization in the private sector. Facilitating environment for a VCoP B is constituted by the values of this organization that include knowledge management, continued development and employees' empow- erment. VCoP B is viewed by the organization as a pilot project the goal of which is to assess whether such communities are adequate tools to increase collective learning among people and to report and share best practices. The communities are not really integrated into the organizational structure and are perceived as an experiment that is officially sanctioned and has a short life span. VCoP members regularly meet face-to-face and they communicate mostly through ICT.

- VCoP C is created by a large organization of public sector that has a high level of resources at its disposal. Managers establish this community in order to fulfil a clear mandate. They are supposed to share best practices for the purpose of (1) standardizing them across decentralized departments, and (2) making recommendations for improvement. Although VCoP C has rather narrow focus and short life span, it is clearly established within the organization the aim of which is to move towards knowledge sharing. Thus it allocates direct resources to the VCoP. All the community members are the organization employees from its various departments. They all have similar knowledge, experiences and areas of specialty. They all work in various regions of the same state and so geographic dispersion of the community is indifferent. They occasionally collaborate - before the community is established, however they do not have much community experience. As a result of their geographical dispersion they never meet face-to-face and mostly rely on technology while communicating.

The classification of VCoPs (Dube et al, 2006) is performed by using the following dimensions: demographics, organizational context, membership characteristics and technology. We can read about it in many recent articles (Tamjidyamcholo, 2013, pp. 416-421, Grabher and Ibert, 2014, pp. 97-123, Jaehong, Eunjung and JoongHo, 2012). Using this typology to scrutinize the three VCoPs, in further part of the article the application of one of the described forms and its effectiveness in practice is presented.

\section{Methods}

The two research methods of an in-depth case study analysis and field research with direct questionnaire were used, in this paper. The case study analysis consists in a comprehensive presentation of a real situation occurring in IT sector in regard to knowledge management tools used within the company which is treated as an individual case. It involves seeking for all necessary data enabling its in-depth analysis, formulating possible choice options and making the best possible decision, accompanied by a proper justification (Wiktor, 1996, p.11). The selected cases deliver both literal and theoretical replication (Perry, 2001, pp.314-315). Results of analyses of articles, particularly of sponsored 
interviews presented in specialist magazine Computerworld and the results of monitoring of Internet webpages of IT sector leaders in Poland are applied in the article. Intel Company, that was selected for the research, is the leader of IT sector in Poland, by revenues from sales of products and services, as presented by the magazine Computerworld ('The biggest IT firms in Poland in 2012' Computerworld 2013). It is also one of the best known companies in market according to respondents.

Direct surveys were performed on a sample of 423 students from public universities in Poland who were studying in mural and extramural programs in Management Departments, during marketing management and global marketing lectures, in 2013 (September-October). The selection of respondents is justified by a high percentage of computer and Internet users in this group of people. It ought to be mentioned that an average Polish young person spends about 18 hours a week on-line. It is nearly twice as much the generation of his/her parents (about 10.7 hours) and three times more than the generation of his/her grandparents (6.1 hours). People with university education (17.1 hours on-line) and secondary education (12.8 hours on-line) are predominant here, by The Youth Report (World Internet Project Poland 2010, p. 34).

For the purpose of identification of VCoP tools, a critical quality analysis of Internet pages selected according to the key notion of ' $\mathrm{VCoP}$ tools' that were updated later than in 2010 was applied. Classification of tools is to a large

Table 1: The tools of $\mathrm{VCoP}$

\begin{tabular}{|c|c|c|}
\hline VCoPA & VCoP B & VCoP C \\
\hline $\begin{array}{l}\text { Social network aimed at specific social } \\
\text { groups (i.e. such as former students - nk.pl } \\
\text { is s a Polish example of such a portal) }\end{array}$ & 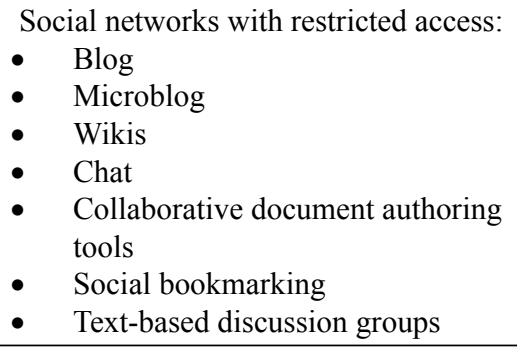 & Narrated (PowerPoint) presentations \\
\hline $\begin{array}{l}\text { Social network aimed at sharing specific } \\
\text { content e.g. YouTube }\end{array}$ & $\begin{array}{l}\text { Tools of personalized online } \\
\text { communication: } \\
\text { - } \quad \text { E-mail } \\
\text { - Skype } \\
\end{array}$ & E-learning tools, e-learning platforms \\
\hline $\begin{array}{l}\text { Social networks connecting closed groups, } \\
\text { which can be joined through an invitation } \\
\text { from another user (e.g. Grono.net) }\end{array}$ & $\begin{array}{l}\text { Face to face tools: } \\
\text { - } \quad \text { Conferences, workshops, knowl- } \\
\text { edge exchange forums } \\
\text { - } \quad \text { Educational programs and spon- } \\
\text { soring education } \\
\text { - } \quad \text { Scientific clubs } \\
\text { - }\end{array}$ & Web conferencing and webcasts \\
\hline $\begin{array}{l}\text { Social networks that provide Internet users } \\
\text { with the opportunity to manage their own } \\
\text { profiles - sites (e.g. Friends.pl, Myspace) }\end{array}$ & & $\begin{array}{l}\text { Online meetings } \\
\text { Online discussions }\end{array}$ \\
\hline $\begin{array}{l}\text { Social networking intended to present } \\
\text { opinions and reviews (e.g., Filmweb, } \\
\text { BilbioNETKA, nuta.pl, opiniuj.pl, dood.pl, } \\
\text { Yelp.com) }\end{array}$ & & $\begin{array}{l}\text { Useful links to: } \\
\text { - } \quad \text { Keyword and full-text searches } \\
\text { (site-wide and by section) } \\
\text { - } \quad \text { Structured databases and database } \\
\text { tools } \\
\text { - } \quad \text { Digital stories } \\
\text { - } \quad \text { Idea banks } \\
\end{array}$ \\
\hline \multirow[t]{2}{*}{$\begin{array}{l}\text { Industry catalogue: of companies and prod- } \\
\text { ucts with social panel added }\end{array}$} & & Subgroup working spaces \\
\hline & & Announcements \\
\hline
\end{tabular}

Source: own case study, based on result of analyses of articles, particularly of sponsored interviews presented in specialist magazine Computerworld and the results of monitoring of Internet web pages of IT sector leaders in Poland and world 
extent a consequence of subjective assessment of tools by their usability for particular forms of VCoP. They are described in chapter 3 .

Apart from descriptive method, the method of simple statistical analyses was applied in the article. Size distribution by selected criteria was applied for analysis of quantitative data. The research results presented in the article are exploratory by nature.

\section{Results}

\subsection{Knowledge management tools in communities of practice}

The tools that convey specific character of particular VCoP in the author's view and that were declared by analysed firms, in sponsored articles, are presented in Table 1.

Online collaborative tools, presented above and used in $\mathrm{VCoP} A$, are the means and mediums of working together on the Internet that facilitate collaboration by individuals who may be located in vastly different geographical areas.
One of the possibilities to change the knowledge is using Social Network Services (SNS). Social networking services are spaces on the Internet where users can create their own profile. They are firstly used to increase the sense of belonging to a social group. These services are divided into two categories: external (external social networking ESN), that are the domain of Community of Practice Network and internal (internal social networking ISN) - closed / private communities composed of groups of people from one network, company, association, educational institution or another organization, but also an ESN-created closed group. The group can be created only through invitation from the present participant. The examples of tools are: YouTube, Grono.net, Myspace, Yelp.com and others. VCoP B type may combine the use of online and offline tools. It makes use of the tools used in the VCoP A, but is distinguished by the use of personalized forms of communication and direct communication (face to face), as the way to create and share knowledge. $\mathrm{C}$ type, while applying mostly ISN tools, constitutes a slightly different form. It is possible for the companies to use the tools belonging to various $\mathrm{VCoP}$ to achieve synergistic effects.

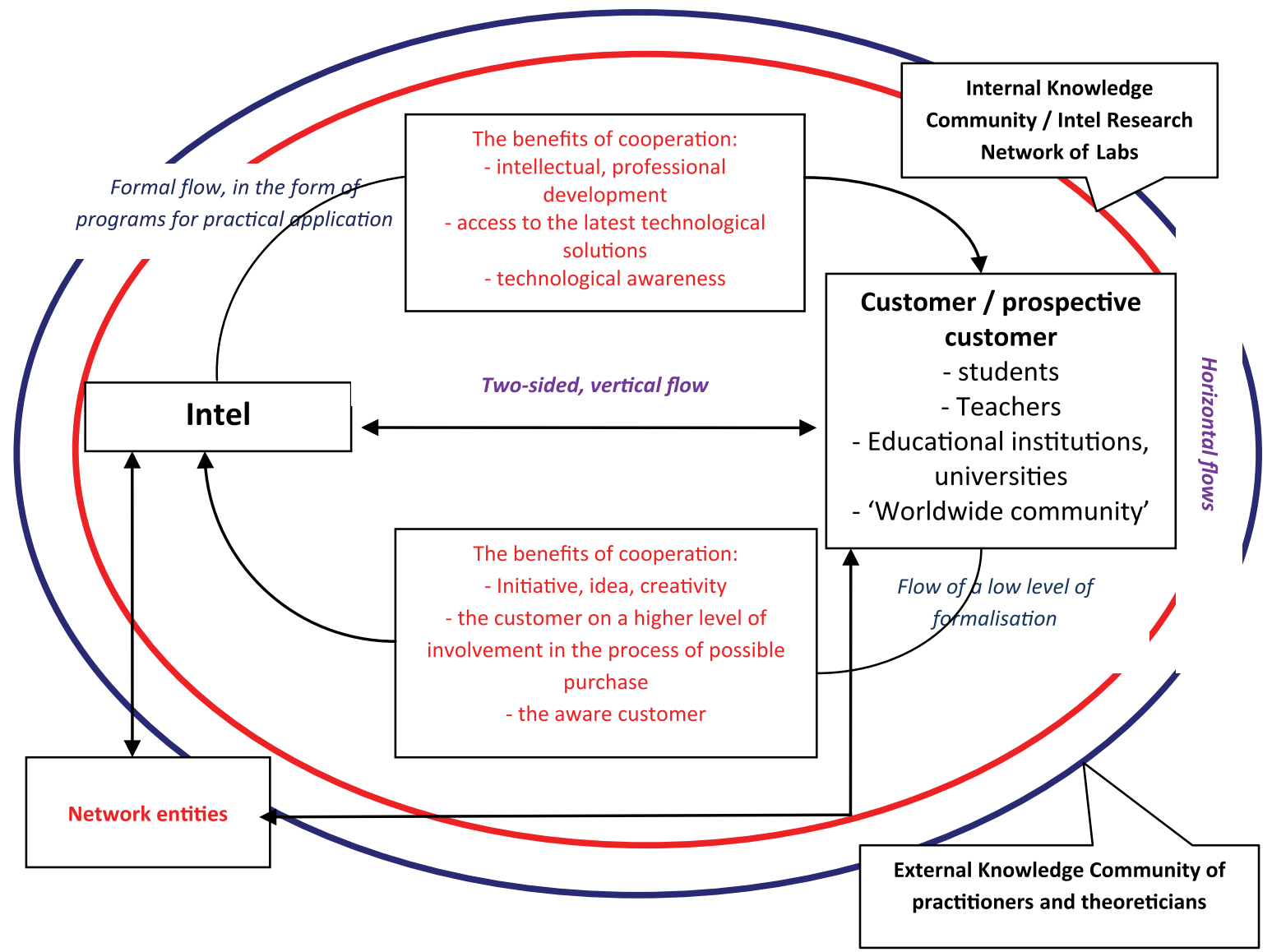

Figure 1: Network flow of knowledge in Intel community of practice. Source: Author 
Table 2: Knowledge of community tools for target groups in the company Intel

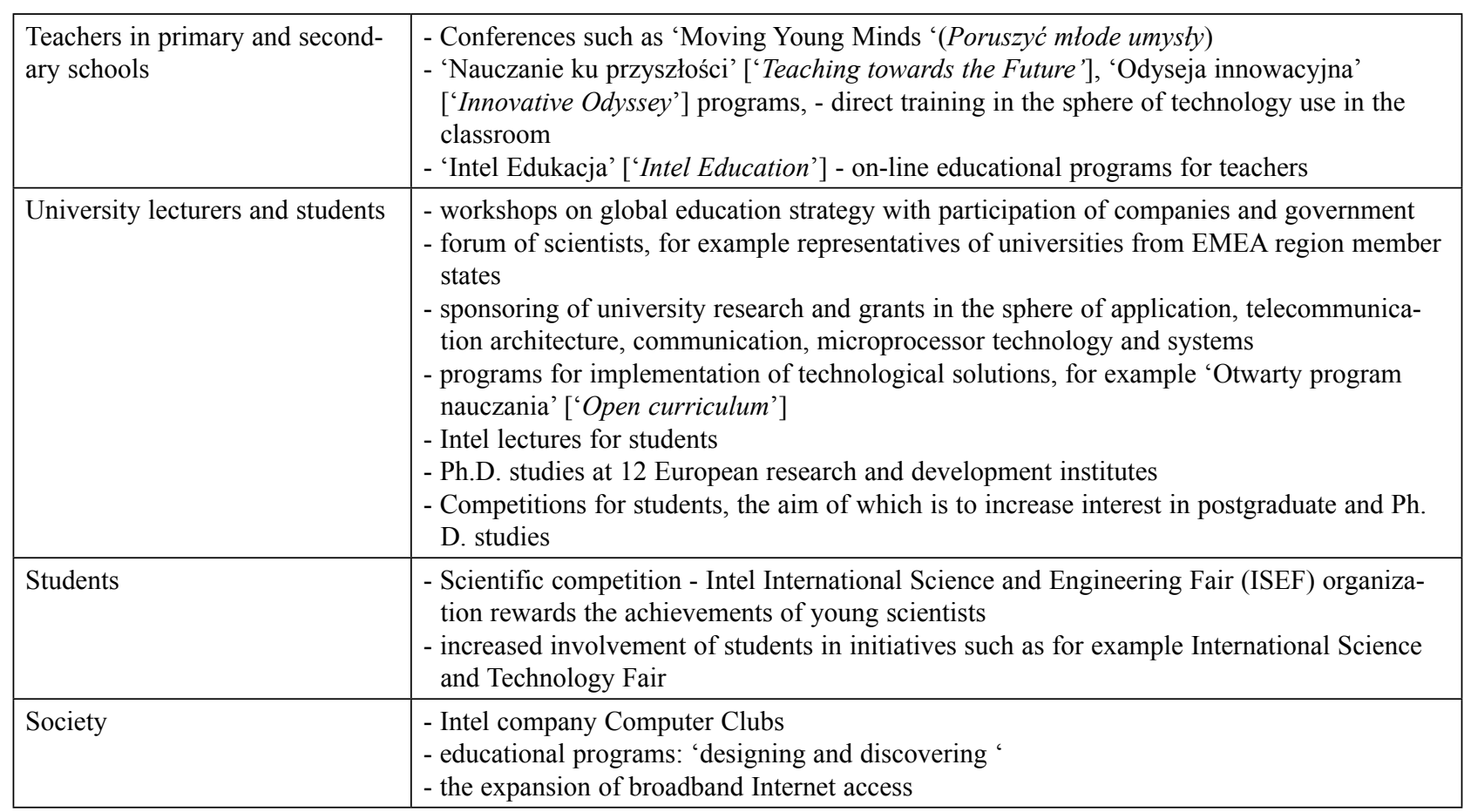

Source: Author

\subsection{Virtual Community of Practice in IT sector - Intel company case study}

The investigated IT company is one of representatives of a convergent sector (telecommunication, IT, media) and offers various products for business, public, home, entertainment or universal purposes. Its common feature is strong engagement in creating knowledge communities and cooperating in this field. The studied company Intel can be classified into VCoP B category. Within created knowledge community, Intel implements Intel Education Initiative program, within World Ahead program (development of the world), that consists in formation of Society of Innovators (Intel Learn Program, Intel Computer Clubhouse Network). It is provided by financial and technological support for various social groups, including: teachers (Intel Teach Program), students (the Intel Science Talent Search, the Intel International Science and Engineering Fair, Intel Schools of Distinction) and Universities (Intel Higher Education Program) throughout the world, especially those specializing in innovative solutions for science, mathematics and technology (Figure 1).

The tools of program implementation in the sphere of strategy of formation and exploitation of community of knowledge in this IT case have social, cultural and also technological nature, with elements of financial support (table 2).

This method of acting is the expression of creation of global community of knowledge, a specific technology park, and thus, the educated target segments. In view of Intel Company, it is also a manifestation of implementation of Intel business ethics program.

Awareness and the level of customer engagement in a Community of Practice - example of Poland

The survey consisting of a questionnaire including 8 substantial questions and 2 others referring to respondents' particulars (place of living and living standards) was filled in by the respondents (Table 3 ).

\section{Table 3: Place of living and living standards of respondents}

\begin{tabular}{|c|c|}
\hline Place of living: A municipality with & No \\
\hline $\begin{array}{ll}\text { - } & \text { more than } 100.000 \text { inhabitants } \\
\text { - } & 50.000 \text { to } 99.999 \text { inhabitants } \\
\text { - } & 10.000 \text { to } 49.999 \text { inhabitants } \\
\text { - } & 5.000 \text { to } 9.999 \text { inhabitants } \\
\text { - } & \text { with less than } 5000 \text { inhabitants }\end{array}$ & $\begin{array}{l}143 \\
98 \\
106 \\
76 \\
0\end{array}$ \\
\hline living standard & No \\
\hline $\begin{array}{ll}\text { - } & \text { 'severe hardship' for level } 1 \\
\text { - } & \text { 'significant hardship' for level } 2 \\
\text { - } & \text { 'some hardship' for level } 3 \\
\text { - } & \text { 'fairly comfortable' living standard for } \\
& \text { level } 4 \\
\text { - } & \text { 'comfortable' living standard for level } 5 \\
\text { - } & \text { 'good' living standard for level } 6 \\
\text { - } & \text { 'very good' living standard for level } 7 .\end{array}$ & $\begin{array}{l}0 \\
26 \\
97 \\
113 \\
106 \\
76 \\
5\end{array}$ \\
\hline
\end{tabular}


The open-ended question: What do you associate the term 'community of practice with'? was most often responded in the following way:

- a group of people who share a common concern and goal

- a group of people who like the same things and buy similar products

- a group of people who is engaged in a process of collective learning

- a group of people that contact the company directly

- a process of learning in groups

- the program of knowledge diffusion

- some institutions and organizations like: universities, scientific groups, even the library.

Most of them have had really big difficulties with defining the term. Most of students answered the question, but the answers were frequently far from being related to the definition of 'knowledge communities'.

While answering the question: "Do you think that you are a member of a community of practice? If so, which one?" most of respondents said that they were not aware of being a part of any community of practice $(73 \%)$. Some of them (nearly 50\%) added that they were possibly the participants in the university community (students' community). Only $12 \%$ said that maybe they were but they could not give any name. 15 per cent of respondents said that they were a part of community of practice in the field of software (7\%), fashion $(5 \%)$, and education $(3 \%)$.

On the other hand, the open-ended question: "What is reflected in your participation in a community of practice?" was responded by stating that the most popular forms of participation in communities of knowledge, in respondents' opinions, are:

- visiting websites

- exchanging opinions between participants

- active participation in classes at university and research groups, with participating practitioners.

The students who participated in the survey are mainly users of Facebook but also 'nasza klasa' and twitter (Table 4)

Table 4: Social media in use

\begin{tabular}{|l|l|}
\hline \multicolumn{1}{|c|}{ Social media } & \multicolumn{1}{c|}{ No } \\
\hline Twitter & 64 \\
\hline Facebook & 148 \\
\hline Yelp & 1 \\
\hline Nasza klasa & 123 \\
\hline GoldenLine.pl & 19 \\
\hline MySpace.com & 26 \\
\hline Grono.net & 14 \\
\hline Wykop.pl & 42 \\
\hline Ask.me & 1 \\
\hline Tumbr.com & 3 \\
\hline vk.com & 2 \\
\hline
\end{tabular}

The students use forums, newsgroups, chat rooms, newsletters and blogs, listed in table 4 .

Table 5: Internet tools in use

\begin{tabular}{|l|c|}
\hline \multicolumn{1}{|c|}{ Other internet tools } & No \\
\hline e-mails & 420 \\
\hline newsletters & 311 \\
\hline blogs & 213 \\
\hline forums, newsgroups, chat rooms & 421 \\
\hline online questionnaires & 19 \\
\hline
\end{tabular}

Unfortunately, despite broad familiarity with Internet tools and declarations of their use, the knowledge of Intel Company projects created for the benefit of community of practice is very poor.

Table 6: Familiarity with the projects of Intel

\begin{tabular}{|l|c|}
\hline Intel's' projects & No \\
\hline $\begin{array}{l}\text { 'Nauczanie ku przyszłości' [Teaching towards } \\
\text { the Future], }\end{array}$ & 11 \\
\hline 'Odyseja innowacyjna' [Innovative Odyssey], & 9 \\
\hline Intel Education project & - \\
\hline $\begin{array}{l}\text { Intel International Science and Engineering Fair } \\
\text { (ISEF) }\end{array}$ & 9 \\
\hline Intel computer clubs & 27 \\
\hline Educational program 'Design and discovery' & 3 \\
\hline other & - \\
\hline
\end{tabular}

Only $14 \%$ students knew at least one example of the Intel projects. Familiarity with other IT companies aimed at sharing knowledge is also unsatisfactory. The students only indicated:

- IBM: Big data, what's all about? - 23 people

- Apple Support Community - 11 people

- Microsoft Support System - 9 people

The question: "Have you ever been invited to participate in any IT community of practice?" was not answered positively by any of the respondents. However, there were some negative answers and in some other cases the question was left unanswered.

\section{Discussion and conclusion}

The entities of the sector in which knowledge is the key resource, and such is the studied entity of the IT sector, apply intensive activities in the sphere of new ways of knowledge creating, acquiring and sharing. In this study, this is expressed by multiplicity of tools used by the studied companies. The tools can be shared into three groups. The most commonly used group of tools by IT firms, in their 
declaration, is group B. It's illustrated by Intel case study, for example. But, the IT companies are aware of possibility to use the tools belonging to various $\mathrm{VCoP}$, to gain synergistic effects, in most opinion.

We can observe noticeable computerization of society, expressed by the aforementioned number of hours spent online per week, particularly by people with secondary and university education. But, the awareness and involvement in community knowledge is marginal. Only 15 per cent of respondents are aware of being a part of any community of practice, despite broad familiarity with Internet tools. The social group that, as it seems, is most active with respect to using computer tools and techniques, does not know the concept of 'knowledge communities' that is intensely created by the IT entities. Only 14 per cent of respondents knew at least one example of the Intel projects. Even if the concept of $\mathrm{CoP}$ was recognized, it was perceived very broadly and generally as a group of people, a group of institutions, a process and program of knowledge diffusion, which altogether made the structure of the studied phenomenon. Declared use of social networking and online tools is rather not associated with participation in the knowledge communities or certainly it is not a conscious activity of the respondents, or a consequence of previous face to face relationships, that were based on the knowledge diffusion.

The results of research are not a consequence of the lack of knowledge of the projects selected to study the entities, because in general, the respondents are not able to name any programs of any company aiming at knowledge exchanging with broadly perceived environment or just the target market. The most of respondents do not show interest in participation in communities of knowledge either, while not consciously seeking this form of relationship with other entities.

This study has shown that despite increasing value of the parameters characterizing Polish Information Society and the involvement of business entities in the process of creating, capturing and expanding knowledge in a new way and according to new principles, the knowledge communities are still in the early stages of their life cycle in conditions of Polish market. This situation concerns a lot of companies, actually, regardless of their level of activity in the processes of conscious knowledge diffusion. It seems that still poor experience in the sphere of formation of the level of knowledge-based relationships result in this state of affairs. Besides, the period of economic crisis experienced by business entities, institutions and customers influence priority character of ventures that have direct impact on financial effects. Therefore, studies of determinants of creation of 'Community of Practice' constitute an interesting field for further studies of the author. This exploratory study is certainly a stimulus for continuation of the study, in field research, of a broader subject scope in international perspective and in a broader time perspective.

\section{References}

Aubry, M., Muller, R., \& Glucker, J. (2011). Exploring PMOs Through Community of Practice Theory. Project Management Journal, 42(5), 42-65, http://dx.doi.org/10.1002/pmj.20259

Bredillet, C. (2004). Projects: Learning at the Edge of Organization, in: P.G. Morris \& J.K. Pinto (Eds.), The Wiley Guide to Managing Projects (pp.1112-1136). Hoboken, NJ: John Wiley \& Sons Inc.

De Long, D,. \& Seemann P. (2000). Confronting Conceptual Confusion and Conflict in Knowledge Management. Organizational Dynamics, 29(1), 33-44, http://dx.doi. org/10.1016/S0090-2616(00)00011-5

Dubé, L., Bourhis, A., \& Jacob, R. (2006). Towards a Typology of Virtual Communities of Practice, Interdisciplinary Journal of Information, Knowledge and Management Vol. 1. Retrieved October 9, 2013 from http://www.ijikm.org/Volume1/ IJIKMv1p069-093Dube.pdf

Duguid, P. (2008). The art of knowing: social and tacit dimensions of knowledge and the limits of the community of practice. In: Amin, A., \& Roberts, J. (Eds.). Community, Economic Creativity and Organization, Oxford: Oxford University Press.

Grabher, G., \& Ibert O. (2014). Distance as asset? Knowledge collaboration in hybrid virtual communities, Journal of Economic Geography, 14 (1), http://dx.doi.org/10.1093/jeg/ lbt014

Gray, B. (2004). Informal Learning in an Online Community of Practice. Journal of Distance Education/Revue de l'enseignement à distance, 19(1), 20-35.

Hara, N., Shachaf, P., \& Stoerger, S. (2009). Online communities of practice typology revisited. Journal of Information Science, No 35(6), http://dx.doi.org/10.1177/0165551509342361

Lave, J., \& Wenger, E. (1991). Situated learning: legitimate peripheral participation, Cambridge: Cambridge University Press, http://dx.doi.org/10.1017/CBO9780511815355

Lee, J., Kim, E., \& Ahn J. (2012). The Effects of Individual and Social Factors on the Knowledge Sharing Activities of the Virtual Community of Practice, Journal of Society for e-Business Studies, 17(2), http://dx.doi.org/10.7838/ jsebs.2012.17.2.023

McDermott, R., \& Archibald, D. (2010). Harnessing Your Staff's Informal Networks. Harvard Business Review. Retrieved August 8, 2010 from http://hbr.org/2010/03/harnessing-yourstaffs-informal-networks/ar/1

Murillo, E. (2011). Virtual Communities of Practice. Theory, Measurement and Organizational Implications. Saarbrücken: VDM Verlag Dr. Müller

Nonaka, I., \& Takeuchi, H. (1995). The knowledge creating company: how Japanese companies create the dynamic of innovation, New York: Oxford University Press

Perry, Ch. (2001). Case Research in Marketing. The Marketing Review, 1, 303-323.

Ranmuthugala, G., Cunningham, F.C., Plumb, J.J., Long, J., Georgiou, A., Westbrook, J.I. \& Braithwaite, J. (2011). A realist evaluation of the role of communities of practice in changing healthcare practice. Implement Science, 6:49, http:// dx.doi.org/10.1186/1748-5908-6-49 
Riverin, S., \& Stacey, E. (2008). Sustaining an Online Community of Practice: A Case Study. Journal of Distance Education/ Revue de l'enseignement à distance, 22(2), 43-58.

Sawhney, M., \& Prandelli, E. (2000). Communities of creation: managing distributed innovation in turbulent markets, California Management Review, 42(4), 24-54, http://dx.doi. org/10.2307/41166052

Scarbrough, H., \& Swan, J. (2008). Project work as a locus of learning: the journey through practice. In: A. Amin \& J. Roberts (Eds.) Community, Economic Creativity and Organization, Oxford, UK: Oxford University Press, pp. 148-177.

Tamjidyamcholo, A., Gholipour, R., Bin Baba, M.S., \& Yamchello, H.T. (2013). Information security professional perceptions of knowledge-sharing intention in virtual communities under social cognitive theory, 3rd International Conference on Research and Innovation in Information Systems (ICRIIS'13) 27-28 November 2013, Selangor, Malaysia, pp. 416-421, http://dx.doi.org/10.1109/ICRIIS.2013.6716746

Wenger, E. (1998). Communities of Practice: Learning, Meaning, and Identity. Cambridge: Cambridge University Press

Wenger, E. (2007). Communities of practice: A brief introduction. Retrieved August 27, 2010 from http://www.ewenger.com/ theory/

Wenger, E., McDermott, R., \& Snyder, W.M. (2002). Cultivating Communities of Practice, Boston: Harvard Business Press.

Wenger, E., \& Snyder, W. (2000). Communities of practice the organizational frontier, Harvard Business Review, January-February, 139-145. Retrieved August 27, 2010 from http://itu.dk/people/
petermeldgaard/B12/lektion \%207/Communities $\% 20$ of $\% 20$ Practice_The $\% 20$ Organizational $\% 20$ Frontier.pdf

Wiktor, J.W.(1996). Studium przypadku. Istota, funkcje i procedura analizy przypadku (Eng. Case Study. The Essence, Functions and Procedures of Case Study Analysis) in: Zarządzanie $i$ przedsiębiorczość. Studia polskich przypadków (Eng. Management and Entrepreneurship. Polish Case Studies) Ed. by J. Altkorna, Warsaw-Cracow: PWN Publishing House World Internet Project Poland (2010), in: Raport Młodzi 2011

[The Youth Report 2011], Chapter: Konsumpcja, czas wolny, nowe media; (Consumption, leisure, new media). Kancelaria prezesa Rady Ministrów (Office of the Prime Minister). Retrieved September 12, 2013 from http://www.zds.kprm. gov.pl/mlodzi-2011, p. 34

Izabela Sztangret holds a Ph. D. in economics in the field of management science. She has been employed since 1995 at the University of Economics in Katowice. Her scientific interests include: knowledge management and marketing knowledge management, particularly in IT sector. Membership in professional organizations: Polish Economic Association in Katowice 1995, Global Academy of Business \& Economic Research 2012, Polskie Naukowe Towarzystwo Marketingu 2013, European Marketing Academy EMAC 2013. 